\title{
Financial performance in Taiwan's ISO14001 environmental management systems (EMS)
}

\author{
Yu-Ling Lin ${ }^{1 *}$ and Tzu-Yar Liu ${ }^{2}$ \\ ${ }^{1}$ Department of Business Administration, National Chin-Yi University of Technology, No. 35, Lane 215, Sec.1, Chung- \\ Shan Road, Taiping City, Taichung County 411, Taiwan. \\ ${ }^{2}$ Energy and Environmental Research Laboratories, Industrial Technology Research Institute, Taiwan.
}

Accepted 15 June, 2011

\begin{abstract}
Numerous empirical studies have examined how voluntary environmental adoption and financial performance are related in enterprises from industrialized countries; little attention has been paid to Taiwanese enterprises. This work empirically explores how IS014001 environmental management systems (EMS) influences the financial performance of Taiwan Stock Exchange (TSE) and over the counter (OTC) listed adopted companies in Taiwan. Based on a sample of 369 ISO14001 certified firms and 706 non-certified firms, the regression results showed that firm age and scale influence firm decisions regarding whether to acquire ISO14001 certification. Measures of profitability, productivity and Research and Development (R and D) competence do not indicate any significant differences between ISO14001 certified and non-certified companies in terms of their financial performance. Since the institutional forces such as greening supply chain pressures have become the major driver of the moves of Taiwanese firms towards more environmentally responsible operations, the estimation results demonstrate that Taiwanese firms regard the ISO14001 standard as an acceptable means of seeking legitimacy, establishing trust and long-term relationships with a wide range of stakeholders, and deflecting the scrutiny and interest of watchdog agencies and other interested parties worldwide; thus, no significant correlation exists between environmental and financial performance.
\end{abstract}

Key words: Certification, environmental performance, financial performance, greening supply chain, ISO14001.

\section{INTRODUCTION}

In an era defined by accelerated population growth and dwindling non-renewable resources, balancing the pursuit of economic growth with environmental conservation is becoming increasingly important in firm policy making. Since 1987, the U.N. World Commission on Environment

${ }^{*}$ Corresponding author. E-mail: yllin2@ms27.hinet.net. or yllin@ncut.edu.tw. Tel: 886-4-23924505. Ext. 7784. Fax: 886-42392-9584.

Abbreviation: TSE, Taiwan Stock Exchange; OTC, over the counter; ISO, International Organization for Standardization; TBT, technical barriers to trade; EA, environmental auditing; EPE, environmental performance evaluation; LCA, life cycle assessment; EL, environmental labeling; EAPS, environmental aspects in product standards; ROI, return on investment; ROA, return on total assets; ROS, return on total revenue; EBIT, earnings before interest and taxation; ROE, return on equity; EPS, earnings per share. and Development has promoted its Agenda 21, inducing nations to device specific policies addressing sustainable development. During the past decade, sustainable development has become a common value worldwide, a way of thinking, and a watchword; national sustainable development policies have made environmental management a key issue in the twenty-first century. Consequently, to achieve the integration and standardization of international environmental management systems, the International Organization for Standardization (ISO) announced the ISO 14000 family of international environmental standards on 1 September 1996. ISO 14001 is the only certifiable environmental management standard within the ISO 14000 family. Moreover, ISO 14001 is widely recognized to be a vital part of the international environmental management movement and an important index for gauging the international competitiveness of enterprises. The ISO 14001 environmental management system standard 
identifies environmental aspects of products, activities, or services of organizations with various types and sizes. In doing so, ISO 14001 thus reduces the adverse environmental impact of such products, activities, or services. The purpose of the ISO in designing the ISO 14001 system is to establish a basic international standard (currently, nations frequently follow their own environmental management systems, for example, the BS 7750 in the U.K., the EMAS in the E.U., Z-750 in Canada, and so on), and establishment of an international standard can avoid the formation technical barriers to trade (TBT), which could hurt both trade and business. Additionally, the ISO aims to promote a responsible attitude among individuals in the "global village."

Winsemius and Guntram (1992) pointed out the emerging awareness of consumers and companies regarding environmental issues; this new wave of thinking regarding sustainable development represents a grassroots force that governments and enterprises cannot afford to neglect. Governments and enterprises thus have increased their commitment to responsible environmental management, implementing policies to address adverse environmental impacts (Mulder, 1998; Walton et al., 1998; Gifford, 1997). Klassen and McLaughlin (1996) believed that enterprises promote environmental management to reduce the negative environmental impacts of their operations. Numerous scholars note that by promoting environmental management, companies are not only operationally successful, but also enhance their environmental performance (Eckel et al., 1992; Greeno and Robinson, 1992; Dean and Brown, 1995; Porter and van der Linde, 1995; Nehrt, 1996; Tibor and Feldman, 1996; Magretta, 1997; Weizsacker and Lovins, 1998; Stigson, 1998; Miles et al., 1999). Miles (1997) further stated that companies will find it difficult to gaining international recognition if they are unable to obtain ISO 14001 certification.

Establishing and implementing an ISO 14001 environmental management system is already of priority concern as enterprises race to carve out a niche in the 21st Century global market. Moreover, implementation of this system is crucial to improving the environmental performance and image of enterprises, which in turn, is critical to boost their production. Because ISO 14001 combines pollution prevention and continuous improvement, companies that operate according to the system's policies, objectives, and benchmarks improve their environmental management system. Becoming ISO 14001-certified marks the beginning of the continual improvement of business system performance. Currently, ISO 14001-certified Taiwanese businesses rank fourth in Asia in terms of numbers, behind China, Japan, and South Korea. Accordingly, ISO 14001 certification is already a widespread trend and an excellent way for Taiwanese companies to sustain their businesses.

Recently, numerous Taiwanese enterprises have promoted ISO 14001 implementation and certification as an effective means of achieving sustainable development. Companies consider ISO 14001 to be viable approaches for helping them cultivate an ideal image and remain competitive attract sales, rather than as a regulation or limitation that brings unwanted stress. This trend also has positive societal effects. Thus, this study attempts to identify qualitative differences between companies with and without ISO 14001 certification. Additionally, this work also attempts to determine the differences in overall operational effectiveness between ISO 14001-certified and non-certified companies in terms of their efforts to balance environmental conservation and sustainable development.

\section{ISO 14001 environmental management systems (EMS)}

During 1996, the ISO promulgated the ISO 14001 environmental management system (designed specifically for evaluating organizations) and other related standards (ISO 14004, 14010, 14011 and 14012), with the aim of providing industries with internationally recognized environmental management regulations and a certification standard. In response to the two key U.N. objectives of improving the environment and achieving sustainable development, ISO subsequently also posted environmental assessments of the products of numerous enterprises. Besides methodology and certification provided to firms by the ISO 14001 system, Technical Committee 207 (Environmental Management) focuses on producing environmental evaluations of firms and their products, and standardizing the rules and definitions of environmental auditing (EA), environmental performance evaluation (EPE), life cycle assessment (LCA), environmental labeling (EL) and environmental aspects in product standards (EAPS).

The Environmental Management System (EMS) comprises the core of the ISO 14000 family and has the serial number ISO 14001 . The system mainly aims to enable environmental conservation via a systemized management program, that is, the system stresses all conservation related matters, enabling management, measurement, improvement and communication via systematic methodology, and does not address pollution prevention, clean-up technology or emission standards. However, the system requires enterprises to prevent pollution or operate within the parameters of sustainable development. ISO 14001 operates based on a voluntary scheme, and provides a new approach to conservation that replaces the command and control system, in which enterprises are led and legally forced by governments to adhere to certain standards. The voluntary scheme enables enterprises to assume responsibility themselves with the expectation that they will inevitably become conscious of the trends and needs of the twenty-first 


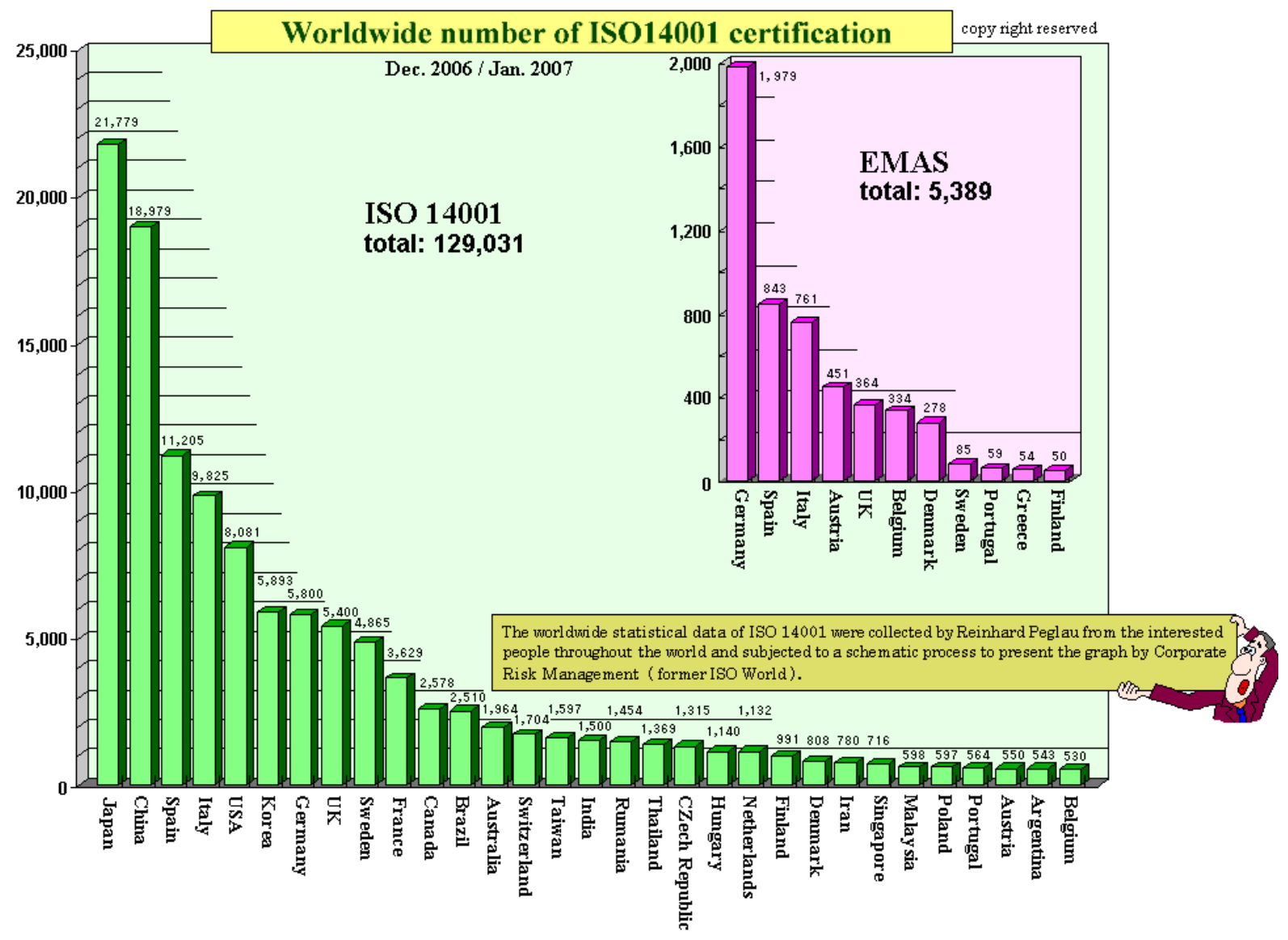
Figure 1. Total no. of ISO 14001-certified
(http://www.ecology.or.jp/isoworld/english/analy14k.htm). enterprises globally. Source: ISOWorld, 2007

century and implement economically sound environmental management plans. Thus, the decision to implement ISO 14001 is voluntary and not binding, unlike the contractual obligations of environmental treaties.

Among the certifications of the ISO 14000 family, ISO 14001 system certification was the earliest to provide official requirements and guidelines for an international standard. ISO 14001 stresses management system, rather than technical pollution emission standard control and pollution testing technology. That is, the essence of the system lies in helping enterprises continually improve their pollution prevention abilities and enhance their environmental performance (Zhang et al., 2000). Accordingly, since promoting certification of the ISO 14000 family, ISO 14001 has increasingly caught the attention of the manufacturing industry along with the ISO 9000 quality management system certification. Certified enterprises have grown rapidly (Montabon et al., 2000; Rezaee, 2000; Chin and Pun, 1999), environmental consciousness is a critical factor in enterprise success, and certification is the only means of sustaining effective business performance (Miles et al., 1999; Magretta, 1997). Greeno and Robinson (1992) felt that the environmental management activities of enterprises will reduce the environmental impact of enterprise business activities, while simultaneously enhancing their environmental performance and competitiveness.

Since Taiwan is a major exporting nation, domestic industries fear that once ISO environmental management standards become industry requirement, they will become new trade barriers. However, industrial, political and academic circles have been actively encouraging industries to promote the establishment and certification of the ISO 14001 system. Based on a survey of ISO 14001-certified enterprises performed by the Federal Environmental Agency in June 1996, the total number of certified Taiwanese enterprises was originally second just behind Japan (Steger, 2000). However, since then the numbers of certified Chinese and South Korean enterprises have overtaken the number of such enterprises in Taiwan. In 2007, certified Taiwanese businesses summed 1,597 out of total 129,031 (Figure 1 ), ranking 15th globally in terms of countries with certified enterprises (ISO world, 2007).

Because ISO 14000 was designed to be compatible with ISO 9000, ISO 9000-certified enterprises can easily 
adopt ISO 14000. Furthermore, small enterprises can integrate the ISO 9000 and 14000 systems, saving manpower and money, and becoming more efficient. Currently, 10,000 Taiwanese businesses have ISO 9001 certification, while 1,597 have ISO 14001 certification. Domestic organizations that have received ISO14001 certification are still at the primary stage in the manufacturing industry likewise, other organizations (such as, government organizations, service industries, hospitals, schools, and so on) are still observing developments from the sidelines, or they do have the difficulties to establish the ISO 14001 system in their organizations.

The usage scope of the ISO 14001 system is such that the system standard requirements are applicable only to those environmental aspects that can be effectively controlled by the organization; the system does not assert any specific principles regarding effective environmental management. ISO 14001 and 14004 standards are simply used to assist organizations in establishing their own management systems, not to force on them regulations to achieve certain objectives. Increasing numbers of enterprises are attempting to become ISO 14001-certified of their own accord and are even requesting that suppliers become certified within certain time periods. ISO 14001 has become a key tool for assessing supplier environmental performance (Miles et al., 1997; Miles et al., 1999; Mohamed, 2001). Tibor and Feldman (1996) felt that companies, following having pushed for ISO 14001 certification, have increased their awareness of environmental issues; became more actively involved in environmental management activities, improved their environmental performance and are more knowledgeable about conducting life cycle analyses and procuring environmentally friendly products. The research of Nakamura et al. (2001) demonstrated that enterprise ISO 14001 certification influences their consumption and procurement of products made from natural resources, such as petroleum products, water, and paper products.

Numerous scholars, both in Taiwan and abroad, hold markedly different views regarding the relationship between the environmental and financial performance of enterprises. Some of them feel that good environmental performance positively influences financial performance. However, others are suspicious of this belief or even posit contradictory theories. Owing to different research themes and the difficulty of balancing environmental and financial performance, the results of different studies differ markedly.

Allen (1992) and Schmidheiny (1992) believed that the environmental performance resulting from promoting environmental activities can actually reduce product costs and waste, and enhance enterprise financial performance. Moreover, enterprise environmental performance can improve profitability (Bragdon and Marlin, 1972; Spicer, 1978) and reduce environmental risk (Spicer, 1978); environmental activities improve enterprise environmental performance (Moskowitz, 1972; Parket and
Eilbirt, 1975; Sturdivant and Ginter, 1977; Arlow and Gannon, 1982; Capon et al., 1990). Furthermore, a positive relationship exists between environmental and financial performance (Bragdon and Marlin, 1972). Enterprises that are active in environmental management can significantly improve their environmental performance and upgrade their financial performance (Callan and Thomas, 1996; llinitch et al., 1998; Wen and Chen, 1998; An et al., 1999; Chin and Pun, 1999; Shi Lixing, Huang Fenghui, Gun Meixiu, 2000; Steger, 2000). The study of Cohen et al. (1995) demonstrated that among large enterprises in the U.S., those with superior environmental performance generally also have good financial performance. However, Nehrt $(1996,1998)$ observed that large enterprises that lead in terms of environmental innovation are typically the fastest way to achieve financial performance.

On the other hand, some scholars maintain that enterprise social responsibilities and financial performance are antithetical (Carter et al., 2000). Vance (1975) and Ullman (1985) both felt that environmental investments increased enterprise production costs and negatively impacted financial performance. Most of the researchers believed that introducing environmental activities into enterprise business operations negatively influences their financial performance (Freeman, 1994; Judge and Hemi, 1994). Moreover, Walley and Whitehead (1994) demonstrated that enterprises generally believe that pushing for environmental-related measures and abiding by related laws and regulations will increase operating costs and negatively impact profitability. Cost increases result from the internalization of costs that were previously external, for example assuming the costs of air pollution (Bragdon and Marlin, 1972; Klassen and McLaughlin, 1996). The research of Jaggi and Freedman (1992) demonstrated that enterprises investing in pollution prevention equipment do not improve their financial performance, that is, no positive relationship exists between environmental and financial performance.

Additionally, some scholars feel that no relationship exists between enterprise social responsibilities and financial performance (Alexander and Buchholz, 1978; Abott and Monsen, 1979). Additionally, no noticeable differential relationship necessarily exists between enterprise environmental disclosure activities and financial performance (Freedman and Jaggi, 1982; Wiseman, 1982) nor is there any noticeable difference between enterprise environmental performance and profitability (Fogler and Nutt, 1975; Rockness et al., 1986). Mahaptra (1984) demonstrated that companies which invest heavily in pollution clean-up are not guaranteed a good environmental performance. Jaggi (1993) felt for businesses that invest in pollution prevention and clean-up equipment, such a move is merely a temporary measure to avoid violating government regulations. Additionally, in the present case, the relationship between environmental and financial performance 
becomes negative. Conversely, if enterprises make a long-term investment in pollution prevention and clean-up equipment, this equipment will boost their market performance, representing a positive relationship between environmental and financial performance.

In synthesizing the above sources, owing to disparities in research subjects and methods, there is obviously still no overarching theory regarding the relationship between environmental and financial performance. This study analyzes the basic characteristics and financial performances of ISO 14001-certified and uncertified Taiwanese listed enterprises based on the research of scholars regarding ISO 14001 environmental management. Regarding an evaluation standard for measuring performance, the Taiwanese stock market breaks down enterprise finances into five categories: profitability, cash flow, ability to pay debt, capital debt management and growth capabilities. These indicators comprise the evaluation system applied to the finances of listed companies. In assessing enterprise financial performance, the business performance, cash flow, and financial circumstances reflect the profitability of that enterprise, and the enterprise goals and demands must be kept in mind when performing financial ratio analysis. Enterprise performance is defined as the degree to which the enterprise has satisfied its objective(s), and the resource use situation facing the enterprise, which respectively indicates enterprise effectiveness and efficiency. Katzell (1975) proposed that the scope of efficiency is rather large and includes performance, productivity and profitability. Numerous scholars believe that financial performance is influenced by manufacturing performance, product effectiveness and market conditions (Cooper, 1979; Cooper and Kleinschmidt, 1987; Zirger and Maidique, 1990).

Although Chakravarthy (1986) found evidence that methodology using profitability as a measure of performance does not accurately determine whether the operations of an enterprise are superior or not, numerous scholars still use financial indicators such as the 14 commonly used measurement parameters identified by Cooper et al. (1986): investment return rates, sales quota return rates, sales income growth rates, cash flow and investment/market share rates, comparative product quality of competitors, comparative promotions of new products by competitors, comparative direct production costs of competitors, product $R$ and $D$, manufacturing $R$ and $\mathrm{D}$, differences in return on investment (ROI), changes in ratio of $\mathrm{ROI}$, and cash flow/investment ratio changes. Cooper et al. (1986) felt that although measures of profitability are limited, they are still important indicators of performance. Bettis and Mahajan (1985) use the ratio of profitability (namely, the average of capital return rate for the past five years) to risk (namely, shortages in capital return rate for the past five years) to measure organization performance. Ranftl (1979) defined productivity as the ratio of investment to output, that is, Research indicates that financial ratio information is clearly related to assessments of financial performance; however, past measurement indicators are based on financial indicators (such as, the definitions of Cohen, Fenn, and Naimon (1995) regarding accounting return rates, the view of Jaggi and Freedman (1992) and Cohen et al. (1995) regarding stock market performance, the suggestions of Jaggi and Freedman (1992) to use P/E ratio to measure stock market performance, and the four indicators used by Fullerton and McWitters (2001) in their research on the influences of enterprise financial performance (namely, earnings before interest and taxation (EBIT), return on total assets (ROA), return on total revenue (ROS) and cash flow). Bragdon and Marlin (1972) used earnings per share (EPS), return on equity (ROE) and ROI as financial indicators to research the relationship between firm environmental and financial performance.

\section{RESEARCH METHODOLOGY}

\section{Measurement indicators and methods}

This study seeks to first understand the current situation of ISO 14001 certification for Taiwanese businesses and to shore up parameters used by academia to assess performance. Regarding indicators for measuring financial performance, the formulas and implications differ from traditional analyses of financial statements and public manuals that classify financial ratios as financial structure, the ability to pay off debt, operational ability, profitability and growth, in that traditional analyses and public manuals are not entirely appropriate for this study. Additionally, this study uses number of employees, total capital and operating quota as indicators to measure enterprise size and to assign the firm to a certain industry category.

In the research methodology section, this study attempts to use static measurements (ROE, ROA, P/E ratio, rate of gross profit) and dynamic measurements (revenue growth rates) to perform $t$-test (when parameters are normally distributed), or to use the Wilcoxon nonparametric test in order to perform the analyses.

\section{Research object}

Taiwan's ISO 14001-certified enterprises include a wide range of enterprise types and sizes. For example, Chinese Petroleum Corp. and Formosa Plastics Corp. have 30 and 9 certified facility levels, respectively. Because this study is focused on the "firm level" rather than the "facility level," all enterprises with at least one ISO 14001certified facility level have been included in the analysis. This work performs a business performance analysis of 1,075 listed companies, 369 of which are certified while 706 are not. These companies cover 12 industries: food, plastics, textiles, electric machinery, electric appliances and cables, medical biotechnology, glass and ceramics, paper, steel, rubber, cars, and electronics.

This investigation uses relevant open source data to determine financial and economic parameters. The data were obtained from TEJ Data Bank, the Market Observation Post System, informational websites, the Safety, Health and Environment Today (SHE) website of the Industrial Economic Bureau of the Ministry of Economic Affairs, and so on.

\section{Research hypothesis}

Jiang and Bansal (2003) believed that ISO 14001 certification is 
Table 1. Basic analysis of ISO 14001-certified and uncertified enterprises.

\begin{tabular}{|c|c|c|c|c|}
\hline Item & & $\begin{array}{l}\text { W/O ISO14001 } \\
\text { certification }\end{array}$ & $\begin{array}{l}\text { W/ISO14001 } \\
\text { certification }\end{array}$ & Pearson square \\
\hline \multirow{3}{*}{ Year of establishment } & Before 1970 & 98 & 117 & \multirow{3}{*}{$165.445^{\star * *}$} \\
\hline & $1971-1990$ & 355 & 211 & \\
\hline & after 1990 & 253 & 41 & \\
\hline \multirow{2}{*}{ Industry type } & Electronics Industries & 479 & 242 & \multirow{2}{*}{0.563} \\
\hline & Others & 227 & 127 & \\
\hline \multirow{4}{*}{$\begin{array}{l}\text { Scope of enterprise: } \\
\text { Numbers of employees }\end{array}$} & Less than 300 employees & 451 & 103 & \multirow{4}{*}{$771.005^{\star \star \star}$} \\
\hline & 300-1000 employees & 195 & 141 & \\
\hline & 1001-3000 employees & 47 & 80 & \\
\hline & More than 3000 employees & 13 & 44 & \\
\hline \multirow{4}{*}{$\begin{array}{l}\text { Scope of enterprise: } \\
\text { Gross revenue }\end{array}$} & Less than 1 billion & 281 & 71 & \multirow{4}{*}{$92.679^{\star \star *}$} \\
\hline & 1-5 billion & 312 & 153 & \\
\hline & 5-10billion & 67 & 44 & \\
\hline & More than 10 billion & 47 & 101 & \\
\hline
\end{tabular}

simply a procedural, legal distinction that has no real bearing on enterprise performance. Consequently, this investigation devises the following hypotheses for determining whether ISO 14001 certification has any bearing on business profitability, productivity, $\mathrm{R}$ and $\mathrm{D}$ capabilities, and overall nature.

$\mathrm{H}_{1}$ : Certified and uncertified enterprises do not differ significantly in terms of their overall nature (namely, age).

$\mathrm{H}_{2}$ : Certified and uncertified enterprises do not differ significantly in terms of size (namely, number of employees, total capital and gross revenue).

$\mathrm{H}_{3}$ : Certified and uncertified enterprises do not differ significantly in terms of their profitability (namely, business growth, profit margin, ROA, ROE and P/E ratio).

$\mathrm{H}_{4}$ : Certified and uncertified enterprises do not differ significantly in terms of their productivity ( amely, operating revenue per employee) H5: Certified and uncertified enterprises do not differ significantly in terms of their $R$ and $D$ capabilities (namely, individual $R$ and $D$ and $R$ and $D$ strength).

\section{FINDINGS}

\section{Empirical findings}

This investigation analyzed the efficiency of ISO 14001 certified and uncertified enterprises. Of those, 369 enterprises were certified, representing $34.3 \%$ of the total. Of the 369 certified enterprises, $65.6 \%$ (or 242 enterprises) belonged to the electronics industry, with $13.3 \%$ (or 49 enterprises) located in the Hsinchu Science Park. Table 1 lists basic statistics.

In the test ( $t$-test) of the differences in averages and analysis of variances, the observed values of different groups should not accord with the normality (normal distribution) hypothesis, and the sample variance should exhibit homogenous variance. In undergoing the Kolmogorov-Smirnov normal distribution test, none of the parameters studied in investigation accorded with the normality hypothesis. Thus, a nonparametric test has been performed to test relevant differences.

From Table 2, certified and uncertified enterprises differ significantly in terms of how old they are. Moreover, certified and uncertified enterprises also differ markedly in terms of total amount of capital, gross revenue, and number of employees. However certified and uncertified enterprises do not differ significantly in terms of profitability, productivity, and $\mathrm{R}$ and $\mathrm{D}$ capability.

\section{Evidence-based discussion}

Estimates of enterprise ages do not support the projections of Hypothesis 1; the evidence presented here indicates that older companies are more likely to seek ISO 14001 certification than younger companies. Hypothesis 2 indicates that firm size (in terms of number of employees, total capital, and gross revenue) does not influence whether that company will implement the ISO 14001 environmental management system and seek to become certified; this hypothesis has been overturned by estimate values listed in Table 2. The implications of what has been discovered from applying Hypotheses 1 and 2 in terms of how enterprise age and size influence environmental policymaking are as follows: Because older or larger enterprises always have considerable liabilities, they are more willing to actively adopt certain measures to ensure their power and health. Additionally, such enterprises have more resources (manpower and 
Table 2. Analysis of nonparametric test of ISO 14001-certified and uncertified enterprises.

\begin{tabular}{llccc}
\hline Facet & Item & Mann-Whitney U statistic & Wilcoxon W statistic & Significance \\
\hline Company features & Company age & 80675 & 148940 & $0.000^{\star \star *}$ \\
& & & & \\
Company scope & Total assets & 80649 & 330220 & $0.000^{\star \star *}$ \\
& Net income & 90732 & 340303 & $0.000^{\star \star *}$ \\
& Numbers of employees & 63550 & 306803 & $0.000^{* \star *}$ \\
Profitability & & & \\
& Net income rate & 128305.5 & 377876.5 & 0.686 \\
& ROA & 121891.5 & 367241.5 & 0.13 \\
& ROE & 126684.5 & 194949.5 & 0.483 \\
& P/E ratio & 123261.5 & 372832.5 & 0.145 \\
Productivity & Growth rate & 122861 & 191126 & 0.135 \\
R and D capability & Revenue per person & 126163.5 & & \\
& R and D per person & 123846 & 194428.5 & 0.462 \\
& R and D Strength & 126071 & 192111 & 0.302 \\
\hline
\end{tabular}

material and financial resources), technical capability, wherewithal, and motivation than small to medium-sized enterprises and thus are better positioned to achieve sustainable development. Finally, enterprises must devote considerable resources to establishing and maintaining the ISO 14001 environmental management system to upgrade their environmental performance and achieve sustainable development (Wu et al., 2007). Additionally, Hartman et al. (1997) have observed that enterprise size influences its environmental performance; owing to the benefits of pollution prevention equipment depending on enterprise scope and size, with large enterprises being more likely to seek to become ISO 14001-certified.

Hypothesis 3 predicts that certification will not influence enterprise profitability (in terms of sales growth rates, profit margins, ROA, ROE, and P/E ratio). Moreover, hypothesis 4 illustrates that certification does not influence productivity (in terms of operating revenue per employee). These two hypotheses are supported by the statistics in Table 2. The implications of the results of applying Hypotheses 3 and 4 in terms of how profitability and productivity are influenced when enterprises engage in environmental managing are as follows: First, Taiwanese industry is an important link in the global supply chain. Additionally, the main customers of Taiwanese enterprises are from Japan, Europe, and North America, and are especially focused on environmental issues. Because Taiwanese industry is facing direct pressure from competitive organizations in developed countries (such as, supply chain pressure generated from Dell, SONY, HP, IBM and Ford), seeking ISO14001 certification has become a priority for Taiwanese industries. ISO 14001 certification represents a "green passport" ensuring that Taiwanese firms can continue to export to European and North American markets and failure to possess such certification can translate into a loss of business opportunities for domestic businesses (Bansal and Bognor, 2002). Once the influence of organizational pressure on legal structures, environmental conservation groups, and market demand grows, export-oriented industries like those of Taiwan will increasingly bear the pressure of the global greening supply chain, and will view the ISO 14001 standard as an acceptable legitimacy tool. ISO 14001 can assist Taiwanese businesses in communicating with various competitive global organizations, and gaining international trust and fostering long-term partnerships (Jiang and Bansal, 2003), thus increasing the legitimacy of exchanges (Suchman, 1995). Finally, ISO 14001 certification of Taiwanese businesses contributes to achieving a long term profit and is unlikely to produce gains in less than a year. Accordingly, annual profit margins are unlikely to be good indicators of firm long-term profits. Because of the instability of annual profit margins, this is unlikely to discernibly affect policy decisions to achieve ISO 14001 certification.

Hypothesis 5 predicts that ISO 14001 certification has no bearing on $R$ and $D$ capability, and this hypothesis is supported by the evidence in Table 2. This hypothesis also accords with the results of $\mathrm{Wu}$ et al. (2005), indicating that enterprise $R$ and $D$ capability does not influence its decision to become ISO 14001-certified. This phenomenon indicated that Taiwanese businesses do not normally actively seek to create innovative solutions while heavily investing in environmental improvement, a strategy that would create a win-win situation (Porter and van der Linde, 1995). Furthermore, previous empirical studies have also demonstrated that environmental 
innovation typically occurs in competitive global industries (Brunnermeier and Cohen, 2003). Consequently, if Taiwanese businesses wish to play a key role in the world economy, they must cater to global green movement.

\section{CONCLUSIONS AND RECOMMENDED RESEARCH DIRECTIONS}

Enterprises must simultaneously consider their economic growth and environmental conservation in improving their financial and environmental performance. In implementing the ISO 14001 environmental management system, enterprises not only work towards fulfilling their environmental duties, but can also reduce production costs and resource consumption as well as eliminating international trade barriers and doing business in a more "green" fashion. Taking the initiative to become certified is necessary in improving international competitiveness in a world dominated by organizational pressures and market demands. Certification is positively recognized in relation to environmental performance; whether or not certification also significantly influences financial performance remains uncertain.

The results of this study indicate that among listed Taiwanese companies, ISO 14001 certification did not influence profitability, productivity and $R$ and $D$ capability. However, regarding overall enterprise nature, for instance, its age a noticeable difference exists. Simultaneously, a noticeable difference also exists between certified and uncertified enterprises in terms of their size, either in terms of their total amount of capital or gross revenue or their number of employees. Moreover, differences also exist in terms of $R$ and $D$ capability.

Since this study used a sample from the Taiwanese manufacturing industry, its findings are limited. Differences in the conclusions of scholars obtained in similar studies can be attributed to the industry investigated, the time of the investigation, and the use of source materials. This study analyzed a sample of Taiwanese certified and uncertified enterprises during 2004, and the results herein could be made more complete by blending time sequences. Additionally, since certification increases competitiveness over an extended period, post-certification performance can be assessed by tracking. Simultaneously, the samples were not equal in number (namely, the certified and uncertified samples). A comparative assessment of the performance of comparable samples may yield more abundant results. Future related studies should improve upon these areas.

\section{REFERENCES}

Abott WF, Monsen RJ (1979). On the Measurement of Corporate Social Responsibility: Self-Reported Disclosures As a Method of Measuring Corporate Social Involvement. Acad. Manage. J., 22(3): 501-515. Alexander JG, Buchholz RA (1978). Research Notes Corporate Social
Responsibility and Stock Market Performance. Acad. Manage. J. 21(3): 479-486.

Allen FE (1992). Reducing Toxic Waste Produces Quick Results. The Wall Street Journal. New York. August. 11. B1.

An BY, Hsu ML, Liu CC (1999). The Environmental Management of the Food Industry in Taiwan - An Implementation Perspective. J. Technol. Manage., 4(1): 147-174 (in Chinese).

Arlow P, Gannon MJ (1982). Social Responsiveness, Corporate Structure and Economic Performance. Acad. Manage. Rev., 7(1): 235-241.

Bansal P, Bogner WC (2002.) Deciding on ISO14001: Economics, Institutions and Context. Long Range Plann., 35: 269-290.

Bettis RA, Mahajan V (1985). Risk/Return Performance of Diversified Firms. Manage. Sci., 31: 785-799.

Bragdon JH, Marlin J (1972) . Is Pollution Profitable? Risk Management. 19(4): 9-18.

Brunnermeier SB, Cohen MA (2003). Determinants of Environmental Innovation in US Manufacturing Industries. J. Environ. Econ. Manage., 45: 278-293.

Callan SJ, Thomas JM (1996). Environmental Economics and Management: Theory, Policy and Applications. Irwin. Chicago.

Capon N, Farley JU, Hoeing S (1990). Determinants of Financial Performance: A Meta-Analysis. Manage. Sci., 36: 1143-1159.

Carter CR, Kale R, Grimm CM (2000). Environmental Purchasing and Firm Performance: An Empirical Investigation. Transp. Res. Part E., 36: 219-228.

Chakravarthy BS (1986). Measuring Strategic Performance. Strategic Manag. J., 7(5): 437-458.

Chin KS, Pun KF (1999). Factors Influencing ISO14000 Implementation in Printed Circuit Board Manufacturing Industry in Hong Kong. J. Environ. Plan. Manage., 14(1): 123-124.

Cohen MA, Fenn SA, Naimon J (1995). Environmental and Financial Performance: Are They Related? Investor Responsibility Research Center. Washington. DC.

Cooper AC, Willard GE, Woo CY (1986). Strategies of High Performing New and Small Firms: A Reexamination of the Niche Concept. J. Bus. Venturing., 1(3): 247-260.

Cooper RG (1979). The Dimensions of Industrial of Industrial New Product Success and Failure. J. Mark., 43(3): 93-103.

Cooper RG, Kleinschmidt EJ (1987). New Products: What Separates Winners from Losers. J. Prod. Innov. Manage., 4: 169-184.

Dean T, Brown R (1995). Pollution Regulation as a Barrier to New Firm Entry: Initial Evidence and Implications for Future Research. Acad. Manage. J., 38(1): 288-303.

Eckel L, Fisher K, Russell G (1992). Environmental Performance Measurement. CMA Magazine. Mar, pp.12-20.

Fogler HR, Nutt F (1975). A Note on Social Responsibility and Stock Valuation. Acad. Manage. J., 18: 155-160.

Freedman M, Jaggi B (1982). The SEC's Pollution Disclosure Requirements - Are They Meaningful? Calif. Manage. Rev,. 24(2): 60-67.

Freeman PK (1994). Integrating Environmental Risk into Corporate Strategy. Risk Manage., 41(7): 54-59.

Fullerton RR, McWtters CS (2001). The Production Performance Benefits from JIT Implementation. J. Operations Manage., 19(1): 81 96.

Gifford D (1997). The Value of Going Green. Harvard Bus. Rev., 75(5): 11-12.

Greeno L, Robinson SN (1992). Rethinking Corporate Environmental Management. The Columbia J. World Bus., 27 (3/4): 222-232.

Hartman RS, Huq M, Wheeler D (1997). Why Paper Mills Clean Up: Determinants of Pollution Abatement in four Asian Countries. Policy Research Working Paper No. 1710. World Bank. Washington. D.C.

llinitch AY, Soderstrom NS, Thomas TE (1998). Measuring Corporate Environmental Performance. J. Account. Public Policy. 17(4, 5): 383408.

Jaggi B (1993). Impact of Pollution Performance of Pulp and Paper Firms on Their Economic Performance. Working Paper. Rutgers University.

Jaggi B, Freedman M (1992). An Examination of Impact of Pollution Performance on Economic and Market Performance: Pulp and Paper 
Firms. J. Bus. Finance Account., 19(5): 697-713.

Jiang R, Bansal P (2003). Seeing the Need for ISO14001. J. Manage. Stud., 40(4): 1047-1067.

Judge (Jr.) WQ, Hemi K (1994). An Empirical Investigation of the Scope of Firms' Enterprise Strategy. Bus. Society, 33(2): 167-91.

Katzell ME (1975). Productivity: The Measure and the Myth. New York: Amacom.

Klassen RD, McLaughlin CP (1996). The Impact of Environmental Management on Firm Performance. Manage. Sci., 42(8): 1199-1214

Magretta M (1997). Growth through Global Sustainability: An Interview with Monsanto's CEO. Harvard Bus. Rev., Jan-Feb: 78-90.

Mahaptra S (1984). Investor Reaction to Corporate Social Accounting. J. Bus. Financ. Account., 11(1): 29-40.

Miles MP, Manila LS, Russell GR (1997). Marketing and Environmental Registration/Certification What Industrial Marketers Should Understand About ISO14000. Industrial Mark. Manage., 26(4): 363370.

Miles MP, Munilla LS, Mcclurg T (1999). The Impact of ISO14000 Environmental Standards on Small and Medium Sized Enterprises. J. Qual. Manage., 4(1):111-122.

Mohamed ST (2001). The Impact of ISO14000 on Developing World Business. Renewable Energy. 23: 579-584.

Montabon F, Manly SA, Sroufe R, Clanton RC (2000). ISO14000: Assessing its Perceived Impact on Corporate Performance. J. Supply Chain Manage., 36(2): 4-16.

Moskowitz MR (1972). Choosing Socially Responsible Stocks. Bus Society Rev., 1(1): 71-75.

Mulder L (1998). Green Purchasing: Does It Make Sense. Electronics and The Environment. ISEE-1998. Proceedings of the 1998 IEEE International Symposium, pp. 123-128.

Nakamura M, Takahashi T, Vertinsky I (2001). Why Japanese firms choose to certify: A study of managerial responses for environmental issues. J. Environ. Econom. Manage., 42: 23-52.

Nehrt C (1996). Timing and Intensity Effects of Environmental Investments. Strateg. Manage. J., 17: 535-547.

Nehrt C (1998). Maintainability of First Mover Advantages When Environmental Regulations Differ Between Countries. Acad. Manage. Rev., 23(1): 77-97.

Parket IR, Eilbirt H (1975). Social Responsibility: The Underlying Factors. Bus. Horizons. 18(4): 5-10.

Porter ME, van der Linde C (1995). Green and Competitive: Ending the Stalemate. Harvard Bus. Rev., September-October, pp. 120-134.

Ranftl RM (1979). A Productivity Profile...Guidelines to Productive Management. Manage. Rev., 68(11): 49-54.

Rezaee Z (2000). Help Keep the World Green. J. Account., 190(5):5764.

Rockness J, Schlachter P, Rockness HO (1986). Hazardous Waste Disposal, Corporate Disclosure, and Financial Performance in the Chemical Industry. In M. Neimark (Ed.). Advances in Public Interest Accounting. 1(1): 167-191. Greenwich. CT: JAI Press.

Schmidheiny S (1992). Changing Course: A Global Business Perspective on Development and the Environment. MIT Press. Cambridge. MA.
Spicer BH (1978a). Investors, Corporate Social Performance and Information Disclosure: An Empirical Study. Account. Rev., 53: 94111.

Spicer BH (1978b). Market Risk, Accounting Data, and Companies' Pollution Control Records. J. Bus. Financ. Account., 5: 67-83.

Steger U (2000). Environmental Management System: Empirical Evidence and Further Perspectives. Eur. Manage. J., 18(1): 23-37.

Stigson B (1998.) Sustainability in an era of Globalization: The Business Response. In: OECD. Globalization and the Environment: Perspectives from OECD and Dynamic Non-Member Countries. OECD. Paris, pp. 59-64.

Sturdivant FD, Ginter JL (1977). Corporate Social Responsiveness: Management Attitudes and Economic Performance. California Manage. Rev., 19(3): 30-39.

Suchman MG (1995). Managing Legitimacy: Strategic and Institutional Approaches. Acad. Manage. Rev., 20: 571-610.

Tibor T, Feldman I (1996). ISO 14000: A Guide to the New Environmental Management Standards. Irwin Professional Publishing. Chicago. IL.

Ullman A (1985). Data in Search of a Theory: A Critical Examination of the Relationship among Social Performance, Social Disclosure, and Economic Performance. Acad. Manage. Rev., 10: 540-577.

Vance S (1975). Are Socially Responsible Corporations Good Investment Risks? Manage. Rev., 64(8): 18-24.

Walley N, Whitehead B (1994). It's Not Easy Being Green. Harvard Business Review. 72(3): 46-51.

Walton SV, Handfield RB, Melnyk SA (1998). The Green Supply Chain: Integrating Suppliers into Environmental Management Processes. Int. J. Purch. Mater. Manage., 34(2): 2-11.

Weizsacker EU, Lovins AB, Lovins LH (1998). Factor Four: Doubling Wealth. Halving Resource Use. London: Earthscan Publications.

Wen JD, Chen MK (1998). Implementation of ISO14000 in Taiwan. Chung Shan Management Review. 6(1): 195-219.

Winsemius P, Guntram U (1992). Responding to the Environmental Challenge. Business Horizons. 35(2): 12-20.

Wiseman J (1982). An Evaluation of Environmental Disclosures made in Corporate Annual Reports. Account. Organiz. Society, 7: 53-63.

World Commission on Environment and Development (1987) Our Common Future.

Wu YS, Chu PY, Liu TY (2007). Determinants of a Firm's ISO 14001 Certification - An Empirical Study of Taiwan. Pacific Econ. Rev., 12(4): 467-487.

Zirger BJ, Maidique M (1990). A Model of New Product Development: An Empirical Test. Manage. Sci., 36: 867-883. 